ノート・ Note

\title{
赤外線反射スペクトルによる $\mathrm{Li}_{2} \mathrm{O}-\mathrm{SiO}_{2}$ 系急冷融液の 加熱処理と構造変化の検討
}

\author{
高嶋廣夫・長江肇・杉山豊彦 \\ (名古屋工業技術試験所) \\ (1984 年 8 月 13 日受付)
}

\section{Structural Change of $\mathrm{Li}_{2} \mathrm{O}-\mathrm{SiO}_{2}$ Glasses by Heat Treatment Using Infrared Reflection Spectroscopy}

\author{
Hiroo TAKASHIMA, Hajime NAGAE and Toyohiko SUGIYAMA \\ (Government Industrial Research Institute, Nagoya) \\ 1-1, Hirate-cho, Kita-ku, Nagoya-shi 462
}

[Received August 13, 1984]

\begin{abstract}
Key-words : Infrared reflection, Structure of $\mathrm{Li}_{2} \mathrm{O}-\mathrm{SiO}_{2}$ glass system, $\mathrm{Li}_{2} \mathrm{O} \cdot 2 \mathrm{SiO}_{2}$ crystallization
\end{abstract}

\section{1. まえがき}

アルカリケイ酸塩急冷融液 (以下ガラスと表記する) で $\mathrm{K}_{2} \mathrm{O}-\mathrm{SiO}_{2}$ は分相し難く, $\mathrm{Na}_{2} \mathrm{O}-\mathrm{SiO}_{2}$ 系は分相が容 易である ${ }^{1)}$. しかも， $\mathrm{Li}_{2} \mathrm{O}-\mathrm{SiO}_{2}$ 系ガラスは，これらの うち最も分相傾向が大きく, かつ, $\mathrm{Li}_{2} \mathrm{O} \cdot 2 \mathrm{SiO}_{2}$ 組成か らなる結晶化を起こすことは，よく知られている. 例え ば, Jaccodine $\mathrm{e}^{2)}$ は $30 \mathrm{Li}_{2} \mathrm{O} \cdot 70 \mathrm{SiO}_{2} \mathrm{~mol} \%$ の゙ラスを $520^{\circ} \mathrm{C}, 560^{\circ} \mathrm{C}, 600^{\circ} \mathrm{C}$ で加熱して $\mathrm{Li}_{2} \mathrm{O} \cdot 2 \mathrm{SiO}_{2}$ 結晶が 析出する様子を顕微鏡で観察し, 結晶の析出と加熱時間 との間の関係を求めている. また, $\mathrm{Vogel}^{3)} も 34 \mathrm{Li}_{2} \mathrm{O}$. $66 \mathrm{SiO}_{2}$ ガラスを $500^{\circ} \mathrm{C}$ で 96 時間加熱して, $\mathrm{Li}_{2} \mathrm{O}$. $2 \mathrm{SiO}_{2}$ の結晶が析出したことを電子顕微鏡で観察してい る. Rindone ${ }^{4)}$ は $\mathrm{Li}_{2} \mathrm{O} \cdot 4 \mathrm{SiO}_{2}$ ガラスから $\mathrm{Li}_{2} \mathrm{O} \cdot 2 \mathrm{SiO}_{2}$ 結晶が析出するとき少量の白金が結晶核生成剤として効 果のあることを明らかにした。 Freiman, Hench ${ }^{51}$ は $\mathrm{Li}_{2} \mathrm{O}-\mathrm{SiO}_{2}$ 系ガラスから $\mathrm{Li}_{2} \mathrm{O} \cdot 2 \mathrm{SiO}_{2}$ 結晶が析出する 速度論をX線回折を用いて研究している.これらの研究 はX線回折や顕微鏡による検討が主なものであった。近 年では Furukawa, White の $\mathrm{Li}_{2} \mathrm{Si}_{2} \mathrm{O}_{5}-\mathrm{TiO}_{2}$ 系ガラスの 結晶化をラマンスペクトルを用いて研究した報告があ $る^{6}$. しかし本研究では溶融後, 急冷したガラスをいろ いろな温度に加熱処理して均一相から分相, 結晶化へと 進む過程を検討するのに赤外線反射スペクトルを主体に して,その挙動を検討した.なお，反射法を用いた理由は， 透過法に比べて粒子の散乱等による影響がないため,
ピークが鋭敏で観察のとき波形並びにピークシフトが判 断しやすいためである。また，本実験における $\mathrm{Si}-\mathrm{O}-\mathrm{Si}$ 結合の反射ピークは $1100 \mathrm{~cm}^{-1}$ 付近に現れ, 透過法の吸収ピークとはほぼ同じ位置にある。これにつ いて, $\mathrm{Simon}^{71}$ は赤外線の斜めの入射角度で試料の反射 スペクトルを測定したとき, 媒体より大きな屈折率をも つ試料での反射は吸収の大きな位置で反射率が高くなる ことを明確にしている．本実験の急冷融液及び結晶は媒 体の空気より屈折率が大きく，その差が充分大きいため 1 回反射法で強い反射強度が得られる. また, 反射スペ クトルは, 試料の屈折率, 吸光係数, 入射角によって支 配されるが, 赤外線によって試料の構造に依存する原子 間の振動現象は実測される反射スペクトルに反映される ので, 直接反射スペクトルによって構造解折を試みても 実用的には充分である。

\section{2. 実験方法}

$\mathrm{Li}_{2} \mathrm{O} \cdot 2 \mathrm{SiO}_{2}, \mathrm{Li}_{2} \mathrm{O} \cdot 3 \mathrm{SiO}_{2}, \mathrm{Li}_{2} \mathrm{O} \cdot 4 \mathrm{SiO}_{2}$ の 3 組成を 用いた，炭酸リチウムとケイ石で配合した各組成の調合 物を白金るつぼに入れて $1300^{\circ} \mathrm{C}, 1 \mathrm{~h}$ 電気炉で溶融し, 鉄板上に流して急冷試料を作った. それを $400^{\circ} \sim 800^{\circ} \mathrm{C}$ の各温度の電気炉に 30 分間投入し, 引き出して加熱処 理試料を作った. 各試料の表面を鏡面反射が得られるま で研磨し, 日立製作所 EPI-G 型を用い, 入射角 $30^{\circ}$ で, $1300 \mathrm{~cm}^{-1} \sim 700 \mathrm{~cm}^{-1}$ の波長域において赤外線反射スペ 
クトルを測定した。また，日立製作所製高分解能電界放 射走查型電子顕微鏡 HFS-25 型，島津製作所製 X 線回 折装置 VD-1 型, 熱膨張, 比重変化等の観察や測定を して, 赤外線反射スペクトルによる挙動追跡の補強測定 とした。

\section{3. 実験結果}

\section{3. $1 \mathrm{Li}_{2} \mathrm{O} \cdot 2 \mathrm{SiO}_{2}$ 組成}

このガラスの $\mathrm{Li}_{2} \mathrm{O}$ と $\mathrm{SiO}_{2}$ の組成モル比は 1 対 2 で ある.このガラスの急冷したものをいろいろな温度に熱 処理した試料の赤外線反射スペクトルを図 1 に示した. このガラスでは，急冷から $600^{\circ} \mathrm{C}$ までスペクトルの極 端な変化はないが，処理温度が上昇するにつれて Si$\mathrm{O}-\mathrm{Si}$ 結合による約 $1050 \mathrm{~cm}^{-1}$ のピークは，わずかに低 波数側に移行した。そのことは，熱処理のため Si-O$\mathrm{Si}$ 結合力が弱くなったことが考えられる．処理温度が $600^{\circ} \mathrm{C}$ を超すと，スペクトルは大きく変化して， $\mathrm{Li}_{2} \mathrm{O}$ ・ $2 \mathrm{SiO}_{2}$ 結晶の析出に伴う変化のあることが分る. 特に $750^{\circ} \mathrm{C}$ の処理温度時点で, 一時的に結晶析出後の原子配 列に変化の起こる様子が赤外線反射スペクトルで観察さ

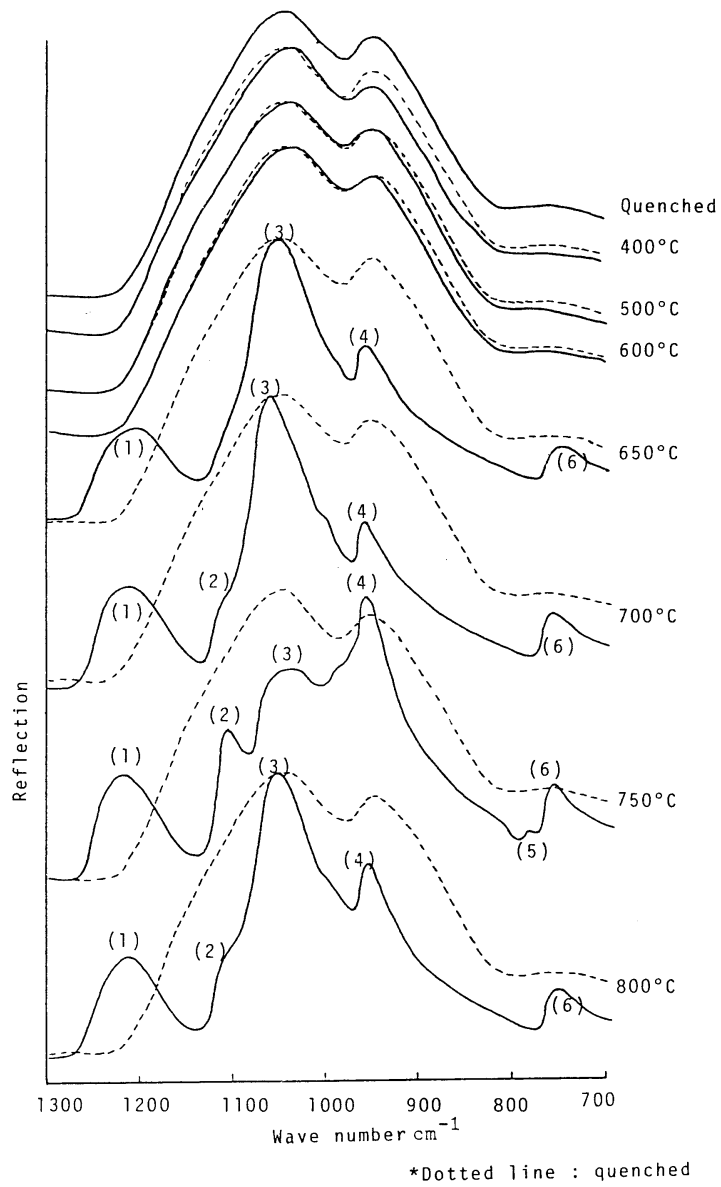

Fig. 1. Infrared reflection curves of $\mathrm{Li}_{2} \mathrm{O} \cdot 2 \mathrm{SiO}_{2}$.
れた。処理温度, $600^{\circ} \mathrm{C}$ 以上において赤外線反射スペク トルに現れた変化，特に結晶化に伴うスペクトルの変化 が $\mathrm{Li}_{2} \mathrm{O} \cdot 2 \mathrm{SiO}_{2}$ 結晶によるものであることは $\mathrm{X}$ 線回折 及び走査型電子顕微鏡で確認した。なお，ケイ酸塩ガラ ス構造の赤外線反射ピークの帰属について, Simon, McMahon $^{81} や$, Jellyman と Procter ${ }^{9)}$ そのほかの研究に より，Si-O-Si 結合については，波長 $9 \sim 9.5 \mu \mathrm{m}$, - $\mathrm{S}$ i-O- $\mathrm{O}^{-}$結合については 10〜11 $\mu \mathrm{m}$ に位置することを 明らかにしている。 また, Mysen, Virgo, Scarfe, Kushiro はラマンスペクトルでケイ酸塩融液体のピーク の帰属を次のように考えた ${ }^{10), 11}$. それによれば, $\mathrm{SiO}_{4}^{4-}$ のモノマーは850〜 $870 \mathrm{~cm}^{-1}, \mathrm{Si}_{2} \mathrm{O}_{7}^{6-}$ ダイマーは 905 $\sim 920 \mathrm{~cm}^{-1}, \mathrm{SiO}_{3}^{2-}$ チェンは $970 \sim 950 \mathrm{~cm}^{-1}, \mathrm{Si}_{2} \mathrm{O}_{5}^{2-}$ シー 卜は $1050 \sim 1100 \mathrm{~cm}^{-1}, \mathrm{SiO}_{2}$ ガラスは $1065 \mathrm{~cm}^{-1}$, $1200 \mathrm{~cm}^{-1}$ と帰属を明らかにしている。このようにケイ 酸塩ガラス構造体は $1000 \mathrm{~cm}^{-1}$ 付近の広い波数範囲に よって反射ピークが観察される.

\section{3. $2 \mathrm{Li}_{2} \mathrm{O} \cdot 3 \mathrm{SiO}_{2}$ 組成}

このガラスの急冷試料は，その状態でも分相状態であ る.これらをいろいろな温度で熱処理をしたものの赤外 線反射スペクトルを図 2 に示す。このガラスは比較的低 温による熱処理, つまり急冷試料を $400^{\circ} \mathrm{C}$ で再加熱し たときでも原子配列の動きのあることが認められた．す なわち $\mathrm{Si}-\mathrm{O}-\mathrm{Si}$ 結合による主ピークの低波数側に肩が 観察され，それは，この系の結晶相の主ピークの位置に 相当した．つまり，この系のガラスは低温でも既に結晶 化への力が働いていることが赤外線反射スペクトルで分

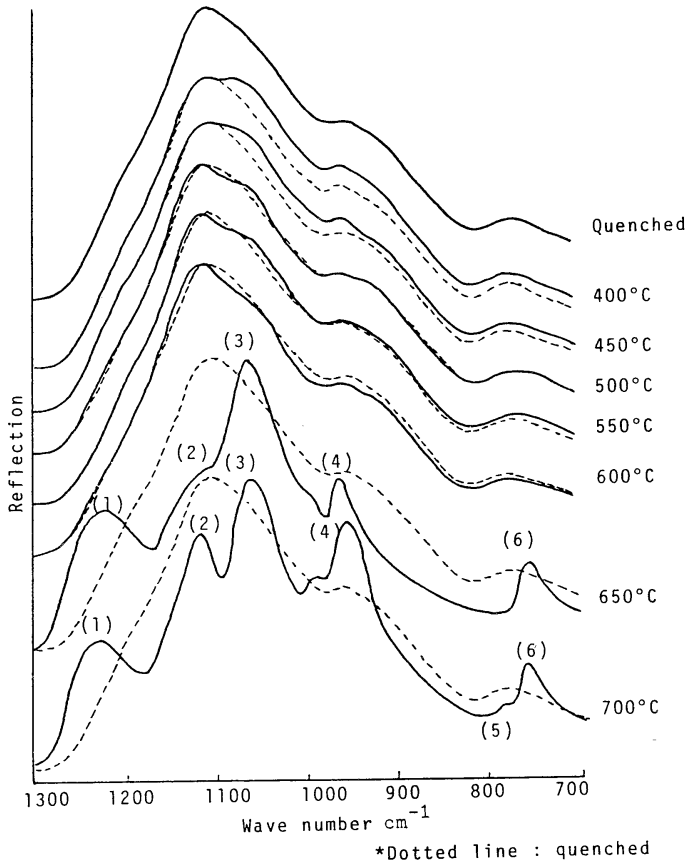

Fig. 2. Infrared reflection curves of $\mathrm{Li}_{2} \mathrm{O} \cdot 3 \mathrm{SiO}_{2}$. 


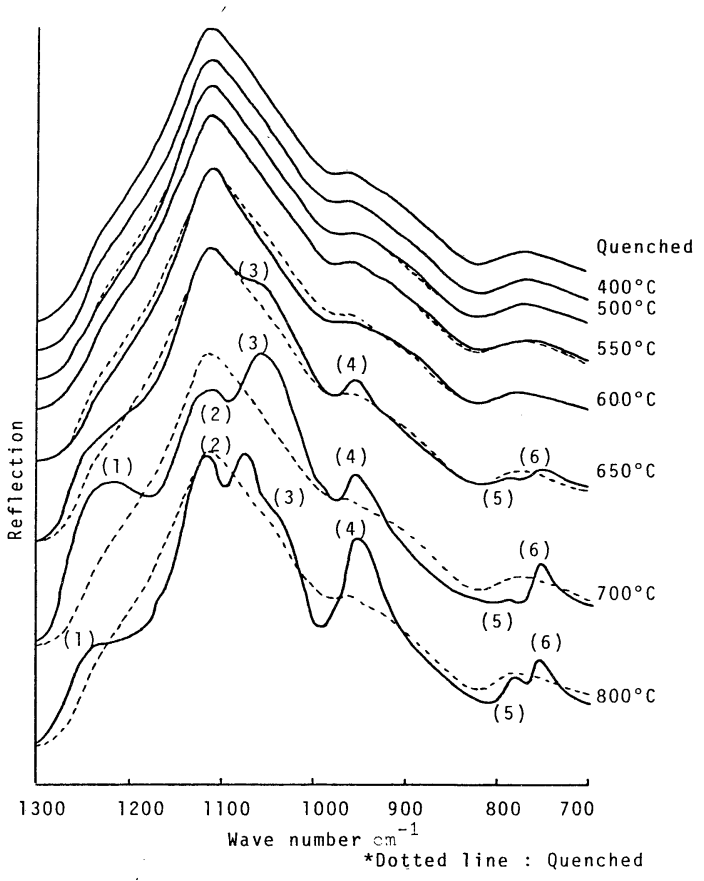

Fig. 3. Infrared reflection curves of $\mathrm{Li}_{2} \mathrm{O} \cdot 4 \mathrm{SiO}_{2}$.

る. 熱処理温度 $500^{\circ} \sim 600^{\circ} \mathrm{C}$ の間ではピークが高波数側 に移行して分相が進行する様子が分る ${ }^{121} .650^{\circ} \mathrm{C}$ 以上で は結晶化した相のスペクトルが観察された.

\section{$3.3 \mathrm{Li}_{2} \mathrm{O} \cdot 4 \mathrm{SiO}_{2}$ 組成}

図 3 に示すように，この組成では急冷から $550^{\circ} \mathrm{C}$ ま で全くスペクトルの変化はなく, $600^{\circ} \mathrm{C}$ で分相進行ある いは結晶化へ移るための原子の動きがピーク幅の狭くな ることによって観察され ${ }^{12)}$, $650^{\circ} \mathrm{C}$ から結晶化へのスペク

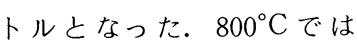
$\mathrm{Li}_{2} \mathrm{O} \cdot 2 \mathrm{SiO}_{2}$ 結晶とともにク リストバライトが析出し，ス ペクトルは,それに伴う波形 となった。

\section{4 熱 膨 張}

図4は三つのガラスの熱膨 張曲線である. $\mathrm{Li}_{2} \mathrm{O} \cdot 2 \mathrm{SiO}_{2}$ ガラスでは, $T_{\mathrm{g}} 430^{\circ} \mathrm{C}$, 軟 化点 $A_{\mathrm{t}} 500^{\circ} \mathrm{C}$, 線熱膨張係 数 $8.3 \times 10^{-6}$ であった。 $620^{\circ} \mathrm{C}$ で結晶化のため押し棒 式熱膨張計で計測したときの 見掛け上の収縮の停止がみら れ, $620^{\circ} \sim 700^{\circ} \mathrm{C}$ で結晶化進 行, それの終了に伴って再び 膨張した. $\mathrm{Li}_{2} \mathrm{O} \cdot 2 \mathrm{SiO}_{2}$ ガラ スでは, $T_{\mathrm{g}} 470^{\circ} \mathrm{C}, A_{\mathrm{t}} 525^{\circ} \mathrm{C}$,
熱膨張係数 $7.0 \times 10^{-6}$ であった. $600^{\circ} \sim 670^{\circ} \mathrm{C}$ の間で結 晶化のための見掛け上の収縮の停止がみられ, それ以後, 再び $700^{\circ} \mathrm{C}$ まで収縮し, $700^{\circ} \mathrm{C}$ から結晶化後の膨張が みられる。 $\mathrm{Li}_{2} \mathrm{O} \cdot 4 \mathrm{SiO}_{2}$ ガラスでは, $T_{\mathrm{g}} 470^{\circ} \mathrm{C}, A_{\mathrm{t}}$ は 不明りょう，熱膨張係数は $5.8 \times 10^{-6}$ であった. $500^{\circ}$ 一 $650^{\circ} \mathrm{C}$ まで分相進行，あるいは結晶化の予備段階ともみ られる幅の広い曲線のピークとなった. $700^{\circ} \mathrm{C}$ 以後は結 晶化終了後の膨張が再び起こる.

\section{5 ガラスの熱処理と比重変化}

図 5 は, それぞれのガラスをいろいろな温度で加熱処 理することによって比重が変化する様子を示した図であ る. 3 種類のガラスで, $\mathrm{Li}_{2} \mathrm{O} / \mathrm{SiO}_{2}$ のモル比が大きいほ ど概して比重は大きい. $\mathrm{Li}_{2} \mathrm{O} \cdot 2 \mathrm{SiO}_{2}$ ガラスでは, $400^{\circ}$ 〜 $600^{\circ} \mathrm{C}$ まで処理温度が上がるにつれて比重は大きく なった. $600^{\circ} \sim 700^{\circ} \mathrm{C} て ゙$ 急に小さくなり，谷ができて， $700^{\circ} \mathrm{C}$ を超えると再び急に大きくなった. $\mathrm{Li}_{2} \mathrm{O} \cdot 3 \mathrm{SiO}_{2}$ ガラスでは, $500^{\circ} \sim 600^{\circ} \mathrm{C}$ で比重のわずかな低下がみら

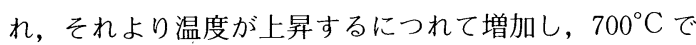
最大となった. $\mathrm{Li}_{2} \mathrm{O} \cdot 4 \mathrm{SiO}_{2}$ ガラスでは, 一時的な比重 の低下はみられず，加熱温度が高くなるほど大きくなっ た。

\section{4. 考 察}

3 種類の組成は，いずれも $650^{\circ} \sim 700^{\circ} \mathrm{C} て ゙ ~ \mathrm{Li}_{2} \mathrm{O}$ ・ $2 \mathrm{SiO}_{2}$ 組成の結晶化が起こった.これは, 今までの多 くの研究者の測定した結晶化温度と一致した.しかし, その温度に至るまでの挙動にそれぞれの違いをみること ができる.つまり, $\mathrm{Li}_{2} \mathrm{O}$ の含有量の高い $\mathrm{Li}_{2} \mathrm{O} \cdot 2 \mathrm{SiO}_{2}$

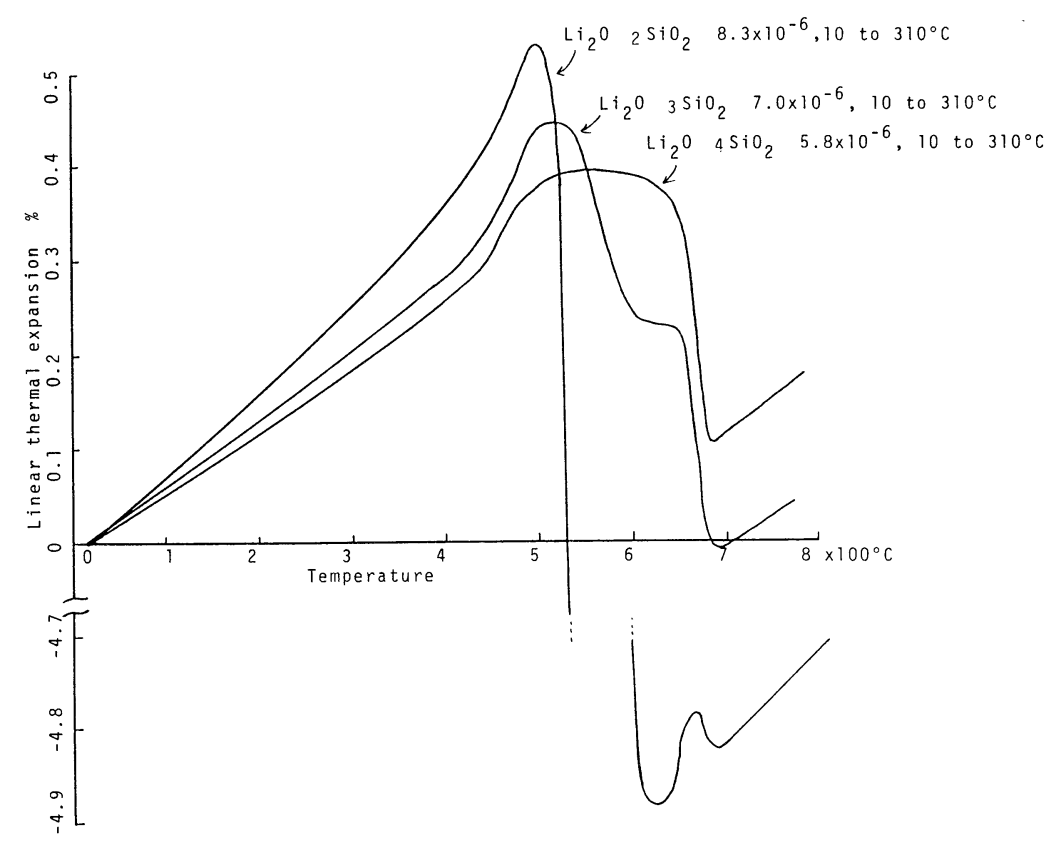

Fig. 4. Thermal expansion curves of glasses. 


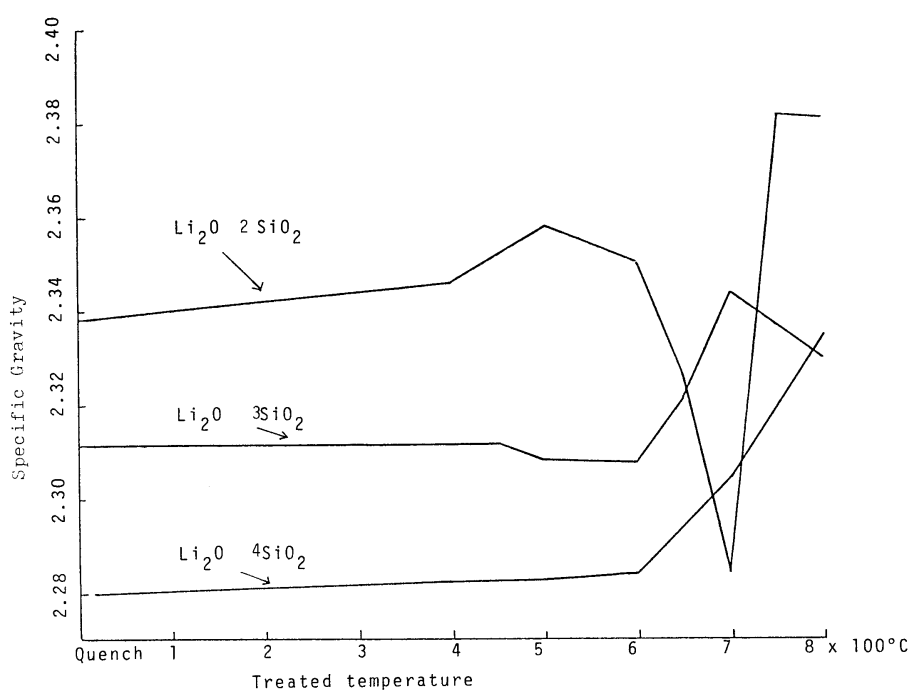

Fig. 5. Change in specific gravity curves of glasses.
結合は弱くなってピークを低波数側に移 行させたものと考えられる.そのように 考えれば $\mathrm{Li}^{+}$イオンの構造引き締め作用 により比重が急冷試料より増加すること が理解できる. $650^{\circ} \mathrm{C}$ で結晶化すること は赤外線反射スペクトルで明らかに分る が結晶化のための原子の移動が起こる段 階では構造が押し広げられて比重は小さ くなる. $750^{\circ} \mathrm{C}$ 以上の処理温度になると 結晶化は終了し, そのときの構造は最も ち密になるため比重は最大となる. $\mathrm{Li}_{2} \mathrm{O} \cdot 3 \mathrm{SiO}_{2}$ ガラスでは, $400^{\circ} \mathrm{C}$ のよう な比較的低温の熱処理でも結晶化への原 子の動きがあることが赤外線反射スペク トルの主ピークに肩が生ずることによっ て分る. 主ピークが高波数側へ移行する のは Si-O-Si 結合が強くなることを示
ガラスでは, $650^{\circ} \mathrm{C}$ で $\mathrm{Li}_{2} \mathrm{O} \cdot 2 \mathrm{SiO}_{2}$ 結晶のみが析出する. その挙動が赤外線反射スペクトルで分る.この赤外線 反射スペクトルの波形が, $\mathrm{Li}_{2} \mathrm{O} \cdot 2 \mathrm{SiO}_{2}$ 結晶によるとい う帰属については, 黄, 横尾, 神谷, 作花ら ${ }^{13)}$ が $\mathrm{Li}_{2} \mathrm{O}-$ $\mathrm{SiO}_{2}$ 系ガラス粉末及び金属アルコキシド溶液の加水分 解によって作ったリチウムケイ酸ゲル粉末の結晶化過程 を研究した中での, $\mathrm{Li}_{2} \mathrm{O} \cdot 2 \mathrm{SiO}_{2}$ 結晶の赤外線吸収スペ クトルを測定しているが，本実験の結晶化による反射ス ペクトルは, それと対比してピークの帰属について考察 した．黄らの実験の高温加熱物，つまり， $930^{\circ} \mathrm{C}, 10$ 時 間処理物は, $\mathrm{Li}_{2} \mathrm{O} \cdot 2 \mathrm{SiO}_{2}$ 結晶であるとしている. その 赤外線吸収スペクトルの谷の位置と本実験の反射ピーク の位置とは一致する. 吸収の谷と反射ピークとの間の関 係については，前述のように，媒質，すなわち，この場 合は空気より大きな屈折率をもつ試料での反射は吸収の 大きな位置で反射率が高くなることを $\mathrm{Simon}^{71}$ が明確に している.このように黄らの $\mathrm{Li}_{2} \mathrm{O} \cdot 2 \mathrm{SiO}_{2}$ 結晶に関す る吸収スペクトルと本研究の反射スペクトルは対称の関 係で比較できる．このように考えて，図 1 図 3 の中に 示した（1)（6) の反射ピークはすべて $\mathrm{Li}_{2} \mathrm{O} \cdot 2 \mathrm{SiO}_{2}$ に関係したピークであるといえる．また，この反射スペ クトルの変化は, 熱膨張曲線と比重の変化を対応させて 考えると一層よく分る. 図 1 の赤外線反射スペクトル で急冷試料と比較して, $400^{\circ} \sim 600^{\circ} \mathrm{C}$ の熱処理試料は Si-O-Si 結合による主ピークがわずかに低波数側に移 行した。それは，ケイ酸 4 面体が立体的に連繫して作ら れる不規則網目構造の間げきの中に $\mathrm{Li}^{+}$イオンが配位 していると思われるが，急冷試料の高温構造の凍結され た状態から熱処理をしたことにより，間げきの中の $\mathrm{Li}^{+}$ イオンが網目構造を引き締め, それによって $\mathrm{Si}$ - $\mathrm{L}-\mathrm{Si}$ 結合の O-Li 間の結合が強くなる. そのため Si-O 間の
している. また, $400^{\circ} \sim 600^{\circ} \mathrm{C}$ の間で比重が減少したの は結晶化傾向による構造の押し広がりを示しているが, このガラスも充分に結晶化すれば，また比重は大きくな る. $\mathrm{Li}_{2} \mathrm{O} \cdot 4 \mathrm{SiO}_{2}$ ガラスは, 急冷しても既に分相状態で あった. それは走査型電子顕微鏡で確認した. 赤外線反

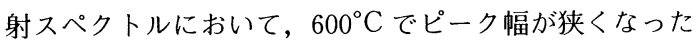
が, それはSi-O-Si 結合のばらつきが小さくなること を意味し，分相が促進したことを示している. $650^{\circ} \mathrm{C}$ 以 上の処理温度で結晶化するのが赤外線反射スペクトルで よく分る. 高温の処理温度で充分結晶化すれば，比重は 大きくなるが, それは, 他のガラス組成と同じである. $\mathrm{Li}_{2} \mathrm{O} \cdot 2 \mathrm{SiO}_{2}$ ガラスの組成比は $\mathrm{Li}_{2} \mathrm{O} \cdot 2 \mathrm{SiO}_{2}$ 結晶と同じ であるので, この場合の結晶は $\mathrm{Li}_{2} \mathrm{O} \cdot 2 \mathrm{SiO}_{2}$ のみでガ ラス全体が結晶化するものと思われる. それよりケイ酸 の多い $\mathrm{Li}_{2} \mathrm{O} \cdot 3 \mathrm{SiO}_{2}$ 組成ガラスでは, 急冷で既に分相 していて, それが発達した後結晶化する. また,このガ ラスの場合は，過剩のケイ酸は石英であることをX線回 折で確認したが，多量のケイ酸過剩量をもつ $\mathrm{Li}_{2} \mathrm{O}$. $4 \mathrm{SiO}_{2}$ ガラスになるとクリストバライトになった. その 理由については現在, まだよく検討していない. Rindone ${ }^{4)}$ は白金を少量添加した $\mathrm{Li}_{2} \mathrm{O} ・ 4 \mathrm{SiO}_{2}$ 系ガラス の結晶化について, Roy ${ }^{14)}$ の研究によるリチウムとアル ミニウムを含有するケイ酸塩において生ずる常温で高温 型石英に近い結晶格子の silica $\mathrm{O}$ が析出することを認め ている.この研究による $\mathrm{Li}_{2} \mathrm{O} \cdot 3 \mathrm{SiO}_{2}$ 組成ガラスが結 晶化する際に認められた石英は silica O かもしれない. このように, ガラスの均一相 $\rightarrow$ 分相 $\rightarrow$ 結晶化の過程は 従来, X線回折, 電子顕微鏡観察が主な研究手段であっ たが，この研究のように赤外線反射スペクトル，熱膨張 曲線及び比重変化を調べることによって, 一層, その挙 動が明確に把握できる. 


\section{5. まとめ}

$\mathrm{Li}_{2} \mathrm{O}-\mathrm{SiO}_{2}$ 系ガラスは分相が容易なガラス系であり， しかも熱処理をすることによって $\mathrm{Li}_{2} \mathrm{O} \cdot 2 \mathrm{SiO}_{2}$ 組成の 結晶が折出する. このガラスが分相 $\rightarrow$ 結晶化する過程 は，電子顕微鏡観察やX 線回折で検討できるが，本報告 では主に赤外線反射スペクトルの変化から検討した．用 いたガラス組成は, $\mathrm{Li}_{2} \mathrm{O} \cdot 2 \mathrm{SiO}_{2}, \mathrm{Li}_{2} \mathrm{O} \cdot 3 \mathrm{SiO}_{2}, \mathrm{Li}_{2} \mathrm{O}$. $4 \mathrm{SiO}_{2}$ 組成である. 3 種類の組成はいずれも $650^{\circ}$ $700^{\circ} \mathrm{C} て ゙ \mathrm{Li}_{2} \mathrm{O} \cdot 2 \mathrm{SiO}_{2}$ 組成への結晶化が起こった. しか し, それまでの温度での組織・構造の変化はX線回折や 電子顕微鏡で検討することはむずかしいが，赤外線反射 スペクトルでは, その状態の変化を観察することができ た. すなわち, $\mathrm{Li}_{2} \mathrm{O}$ の多い $\mathrm{Li}_{2} \mathrm{O} \cdot 2 \mathrm{SiO}_{2}$ 組成ガラスの 急冷試料は均一な単一相に近い. また $600^{\circ} \mathrm{C}$ 付近に加 熱しても分相, あるいは, その発達はみられず, $650^{\circ} \mathrm{C}$ で急に結晶が析出する. また，このガラスは結晶の組成 $\mathrm{Li}_{2} \mathrm{O} \cdot 2 \mathrm{SiO}_{2}$ と同一であったので, 析出する結晶は, $\mathrm{Li}_{2} \mathrm{O} \cdot 2 \mathrm{SiO}_{2}$ 組成のみであった。 それよりケイ酸の多い $\mathrm{Li}_{2} \mathrm{O} \cdot 3 \mathrm{SiO}_{2}$ 組成ガラスでは, 急冷で既に分相していて， それが発達した後, 結晶化する. そのことが, 赤外線反 射スペクトルによって観察された。また，このガラスは 低温の熱処理でもガラス内部の原子配列の変化がみられ ることが特徴で, それは, 赤外線反射スペクトルでよく 分った．更にケイ酸の多い, $\mathrm{Li}_{2} \mathrm{O} \cdot 4 \mathrm{SiO}_{2}$ ガラスでは高 温処理でクリストバライトの析出がみられるのが特徴で
ある.このように $\mathrm{Li}_{2} \mathrm{O} \cdot 2 \mathrm{SiO}_{2}$ 組成ガラスよりケイ酸 の少量の過剩で石英, 多量の過剩でクリストバライトの 析出となる理由は，まだよく検討していない，このよう に均一相 $\rightarrow$ 分相 $\rightarrow$ 結晶化の過程は従来, X線回折, 電 子顕微鏡観察が主な手法であったが, 赤外線反射スペク トル，熱膨張及び比重変化を調べることによって一層そ の挙動が明確に理解できた。

\section{文 献}

1）守屋喜郎, 大工試報告 No. 339 [6]（1971） p. 16.

2) R. J. Jaccodine, J. Am. Ceram. Soc., 44, 472-75 (1966).

3) W. Vogel, Glass Tech., 7, 15-21 (1966).

4) G. E. Rindone, J. Am. Ceram. Soc., 45, 7-12 (1962).

5) S. W. Freiman and L. L. Hench, J. Am. Ceram. Soc., 51, 382-87 (1968).

6) T. Furukawa and W. B. White, Physics and Chemistry of Glasses, 20, 69-80 (1979).

7) I. Simon, J. Opt. Soc. Am., 41, 336-45 (1951).

8) I. Simon and H. O. McMahon, J. Am. Ceram. Soc., 36, 160-64 (1953).

9) P.E. Jellyman and J. P. Procter, J. Soc. Glass Tech., 39, $173 \mathrm{~T}-92 \mathrm{~T}$ (1955).

10) B. O. Mysen, D. Virgo and C. M. Scarfe, Am. Miner., 65, 690-710 (1980).

11) D. Virgo, B. O. Mysen and I. Kushiro, Science, 208, 1370-73 (1980).

12）高嶋廣夫，斎藤 肇，窯協，85，257-63 (1977).

13）黄 占杰, 横尾俊信, 神谷寛一, 作花済夫，窯協， 91, 215-21 (1983).

14) R. Roy, Z. Krist., III, 185-89 (1959). 